\title{
Specificity of induced defenses in Mytilus edulis and asymmetrical predator deterrence
}

\author{
Aaren S. Freeman* \\ Zoology Department, University of New Hampshire, 46 College Road, Durham, New Hampshire 03824, USA
}

\begin{abstract}
Induced defenses of prey have become widely recognized in several marine taxa, yet their specificity to particular predators and impacts on subsequent predation are seldom investigated. In this study, Mytilus edulis showed highly specific induced defenses in response to predators with different attack strategies. The mussels developed significantly heavier shells only in the presence of waterborne cues from Carcinus maenas, a crushing crab predator, and significantly heavier adductor muscles only in the presence of waterborne cues from Asterias vulgaris (= Asterias rubens), a predatory sea star that pries bivalves open. However, mussels effectively thickened their shells in response to cues from predators by either increasing allocation to shell (in response to C. maenas), or reducing linear shell growth (in response to $A$. vulgaris and, to a lesser extent, the predatory whelk Nucella lapillus). These different mechanisms of shell thickening in response to all 3 predators defended the mussels from subsequent crab predation, increasing handling times of mussels by predatory $C$. maenas by more than $48 \%$. In contrast, only mussels with increased adductor muscle weight (an induced response to $A$. vulgaris) were subsequently protected from the sea star. These results suggest that although induced defenses in $M$. edulis are specific to predators with different attack strategies, diffuse selection by C. maenas may allow predator specific responses to be adaptive even when predator composition changes.
\end{abstract}

KEY WORDS: Blue mussel · Asterias vulgaris · Carcinus maenas $\cdot$ Nucella lapillus $\cdot$ Asterias rubens Inducible defense $\cdot$ Phenotypic plasticity

\section{INTRODUCTION}

Inducible defenses are an adaptive response of prey to environments in which predation pressure varies spatially or temporally. Among marine taxa, induced defenses in response to predator cues are widespread and have been observed in barnacles (Lively 1986), bryozoans (Harvell 1984), gastropods (Appleton \& Palmer 1988, Trussell 1996, Trussell \& Smith 2000), and bivalves (Reimer \& Tedengren 1996, Leonard et al. 1999, Smith \& Jennings 2000, Whitlow et al. 2003). The effectiveness of induced defenses is potentially limited by the ability of prey to correctly identify predator cues and express appropriate defensive phenotypes (Moran 1992, DeWitt et al. 1998). Correctly identifying predator cues allows prey to express appropriate defensive phenotypes without the added costs of incongruous, ineffective, or mistakenly expressed defenses (Langerhans \& DeWitt 2002). Although there have been several tests of the specificity of induced defenses elicited by different predators in marine systems (Harvell 1990, Smith \& Jennings 2000, Reimer \& Harms-Ringdahl 2001, Iyengar \& Harvell 2002, Cheung et al. 2004), fully understanding the benefits, disadvantages, and possible selection pressure on induced defenses requires knowing their effectiveness against various predators with different foraging strategies.

Because the expression of many induced morphological defenses require time lags, mismatches can occur between a new predation environment and the prey's induced phenotype (Clark \& Harvell 1992, Padilla \& Adolph 1996, Van Buskirk 2002). In particular, when prey have evolved specific defenses to predators with differing attack strategies, inducible defenses to one 
predator may: (1) provide protection from a second predator with a different attack strategy (Van Buskirk 2001, Laforsch \& Tollrian 2004), (2) leave prey more vulnerable to a second predator (Matsuda et al. 1993, Smith \& Van Buskirk 1995, Turner et al. 1999, DeWitt et al. 2000, Relyea 2001), or (3) have no effect on predation by a different predator. The outcome of predation experiments in systems with multiple predators has only recently been explored, even in well-studied systems such as Daphnia spp. cyclomorphosis (Laforsch \& Tollrian 2004), but may provide a fuller understanding of the adaptive value of inducible defenses in multiple predator environments (i.e. the diffuse selection acting on inducible defenses) (Cipollini 2004, Strauss et al. 2005).

To address the question of specificity of induced defenses and the consequences of this specificity in subsequent predator-prey encounters, I focus on the common, intertidal marine bivalve Mytilus edulis. This bivalve is ideal for the study of specificity of induced defenses because it responds to several predators with very different attack strategies. Several independent studies have shown that $M$. edulis develops thicker, more rounded shells and stronger adductor muscles in response to cues from Asterias spp. (a sea star that pries mussels open) (Reimer \& Tedengren 1996, Reimer \& Harms-Ringdahl 2001) and increases shell thickness in response to cues from the introduced crab Carcinus maenas (a crab that crushes the mussel's shell) (Leonard et al. 1999, Smith \& Jennings 2000, Reimer \& Harms-Ringdahl 2001, Frandsen \& Dolmer 2002) and Nucella lapillus (a whelk that drills through mussel shells) (Smith \& Jennings 2000). Without direct comparisons of induced morphologies it is difficult to determine if the mussel responds to all predators with varying degrees of a similar defensive strategy (Smith \& Jennings 2000), or if different predators induce different traits (Reimer \& Harms-Ringdahl 2001).

Finally, due to annual and inter-annual variation in abundance of various predators (Navarrete et al. 2000, Saier 2001, Witman et al. 2003) the induced morphological defenses of individual mussels may be subjected to disparate predator foraging strategies. Although it is clear mussels expressing induced defenses to Asterias sp. take longer for the sea star to consume (Reimer \& Tedengren 1996), and it is inferred from increased shell strength that mussels expressing induced defenses to Carcinus maenas take longer for the crab to consume (Leonard et al. 1999), it is not clear how these predator specific responses affect handling times of a predator with a different attack strategy. Until recently, there have been remarkably few estimates of effectiveness of induced defenses in mollusks through actual predation trials (but see Reimer \& Tedengren 1996, Cheung et al. 2004) and no tests of their effectiveness against predators with different attack strategies.

Research presented in the present study simultaneously documents the induced defenses of Mytilus edulis in response to waterborne cues from several individual predators: a whelk Nucella lapillus, a sea star Asterias vulgaris (= Asterias rubens; Wares 2001), and a crab Carcinus maenas. In addition to having differing attack strategies, these predators differ in the sizes of mussels consumed; crabs are gape limited creating a size refuge for mussels (Ebling et al. 1964), whereas mussel do not have an absolute size refuge from whelk and sea star predation (Hunt \& Scheibling 1998, Saier 2001). By contrasting the mussel's responses to these predators, I elucidate the ability of these bivalves to distinguish between predators and express defenses appropriate to predators with differing attack strategies. I further determine the effectiveness of these predator specific induced defenses against predators with disparate attack strategies, i.e. the crab, C. maenas and the sea star A. vulgaris.

\section{MATERIALS AND METHODS}

Mussel collection and measurement. To determine the specificity and effectiveness of induced defenses I evaluated the morphology of Mytilus edulis raised with waterborne cues from predators, then exposed similarly induced mussels to predation by Carcinus maenas and Asterias vulgaris. In late June 2002, I collected several hundred mussels from the low intertidal zone at Hilton Park, Great Bay Estuary, New Hampshire, USA $\left(43^{\circ} 7^{\prime} \mathrm{N}, 70^{\circ} 50^{\prime} \mathrm{W}\right)$. From these I randomly selected mussels (12 to $17 \mathrm{~mm}$ shell length, 10 replicate $^{-1}$ ) to be pre-measured for shell mass, length, width, and height. For these measurements length was the greatest anterior to posterior shell dimension, width was the axis perpendicular to the plane formed between left and right shells (when held firmly closed), and height was measured along the dorso-ventral axis, perpendicular to the hinge (see also Smith \& Jennings 2000). To obtain the dry shell mass of live mussels I used the following technique described by Palmer (1982): the immersed mass of a live mussel, suspended in seawater on a mesh net hung beneath a balance (Mettler-Toledo AG204) was measured. For a separate group of immerse-weighed mussels, all tissue was removed and their dry shell weights measured. A regression of these dry shell weights against immersed weights was then used to estimate the dry shell weight of the living, experimental mussels (mussel dry shell weight $=1.5993 \times$ immersed weight $+0.0015, \mathrm{R}$ square $>0.9999, \mathrm{n}=29$ ). Experimental mussel shells were also measured with digital calipers (length, width and 
height; $\pm 0.01 \mathrm{~mm})$. For subsequent identification, I marked each mussel shell with paint pens (916 BriteMark) and sealed paint marks with cyanoacrylate glue.

Experimental apparatus. In a sea table at the University of New Hampshire's Coastal Marine Laboratory (Newcastle) I arranged 20 buckets of 3.51 volume (16 cm tall $\times 18 \mathrm{~cm}$ diameter). All buckets were supplied with a continuous flow of unfiltered seawater via vinyl tubing (1.5 to $21 \mathrm{~min}^{-1}$ ). The 20 buckets were divided into 3 predator cue levels (Nucella lapillus, Asterias vulgaris, Carcinus maenas) and a no-predator control. I collected predators from the rocky intertidal zone adjacent to the marine laboratory and placed predators individually in a single mesh-sided container in each replicate bucket. Seawater escaped each bucket through a dozen holes drilled $2 \mathrm{~cm}$ below the lip of each bucket. All holes were $5 \mathrm{~cm}$ above the water level of the rest of the sea table, such that water from the sea table did not flow back into the buckets and mix predator cues. I used one individual of A. vulgaris and one of $C$. maenas in their respective cue treatments. To provide similar cue levels to all treatments, I compensated for the small size of $N$. lapillus by using 6 whelks replicate $^{-1}$. In addition to the 10 premeasured mussels in each growth chamber, I also raised 32 extra mussels (length 12 to $17 \mathrm{~mm}$ ) for use in a predation experiment (see subsection 'predation experiment' below).

The experiment began on July 7, 2002 and ran for $91 \mathrm{~d}$. Every $4 \mathrm{wk}$ I randomly rearranged buckets in the sea table and fed crushed mussels to the predators. Predators were fed monthly in a separate container and returned to cue containers within $6 \mathrm{~h}$. One Carcinus maenas replicate was excluded from analysis because the crab escaped the mesh-sided container and consumed all the pre-measured mussels. At the end of the experiment, I froze all pre-measured mussels for later morphological measurements. Final morphological measurements were based on the 139 mussels surviving to the end of the experiment (of the original 200 pre-measured mussels).

Morphological statistics. I collected the following final morphological measurements on all premeasured mussels: shell length, shell width, shell height, shell dry weight, tissue dry weight, and posterior adductor muscle dry weight. In order to examine the growth and morphological changes of mussels during the experiments I compared the means of the following for each replicate container (dependent variables are listed first): (1) the residuals of a regression of the final shell weight against the initial shell weight of each mussel, (2) the changes in shell length, width, and height (final measurement-initial measurement) of each mussel, (3) the residuals of a regression of the final shell thickness index (STI) against initial STI. (STI is an integrative estimate of shell thickness and correlates well with multiple measurements of actual shell thickness. STI $=$ dry shell wt $\times\left[\mathrm{L} \times\left(\mathrm{H}^{2}+\mathrm{W}^{2}\right)^{0.5} \times \pi / 2\right]^{-1}$, where $\mathrm{L}, \mathrm{H}$ and $\mathrm{W}$ are length, height and width, respectively (Reimer \& Tedengren 1996, Frandsen \& Dolmer 2002). A multiple regression of measurements of the shell thickness (left and right valves, center and lip) from 48 mussels against STI was well correlated [p $\left.<0.0001, \mathrm{R}^{2}=0.911\right]$ ); (4) the residuals of a regression of final tissue weights against initial shell weights to compare relative tissue growth, and (5) the residuals of a regression of the posterior adductor muscle (dry weight) against the total tissue (dry weight) to determine the amount of tissue allocated to the posterior adductor muscle. In order to preserve experimentwide Type I error, I compared the replicate mean residuals from the above data using a multivariate analysis of variance (MANOVA) and subsequent univariate analyses of variance (ANOVAs). If there was a significant treatment effect in univariate ANOVAs ( $p<0.05)$, I used a priori linear contrasts to compare the means of each predator cue treatment to the control treatment. Because graphs of the above residuals can be difficult to interpret, I used adjusted least square means from a nested analysis of covariance (ANCOVA) of the same relationships to produce Fig. 1. I also compared the outcome of a nested ANCOVA of the above relationships and a nested ANOVA of the residuals from the above regressions to address concerns of potential biases of this residuals technique. These analyses produced similar results, confirmed the homogeneity of regression line slopes, and indicated the residuals technique was appropriate for this data set. Data used in these regressions were untransformed, because exploratory analysis of these data indicated that square-root or log transforming data did not improve the linear fit of bivariate plots. Finally, initial dimensions of mussels did not differ between treatments (all $\mathrm{p}>0.70)$.

Predation experiment. At the end of the $91 \mathrm{~d}$ experimental growth period, after removing the premeasured mussels, I combined the extra 32 mussels from each replicate chamber into a common pool of mussels for each predator cue treatment. In a temperature-controlled room $\left(9\right.$ to $\left.10^{\circ} \mathrm{C}\right)$, I arranged a series of $10,3.51$ predation chambers $(16 \mathrm{~cm}$ high $\times 18 \mathrm{~cm}$ diameter) such that each replicate chamber could be viewed from above through a video camera housed on a tripod. Black plastic hung around the tripod and predation chambers also minimized visual disturbance of crabs. I placed one male Carcinus maenas (carapace width 48 to $59 \mathrm{~mm}$ ) in each chamber and began predation trials. All crabs were healthy, with intact claws etc. After commencing recording with the video camera, a single pre-measured mussel, randomly selected from 

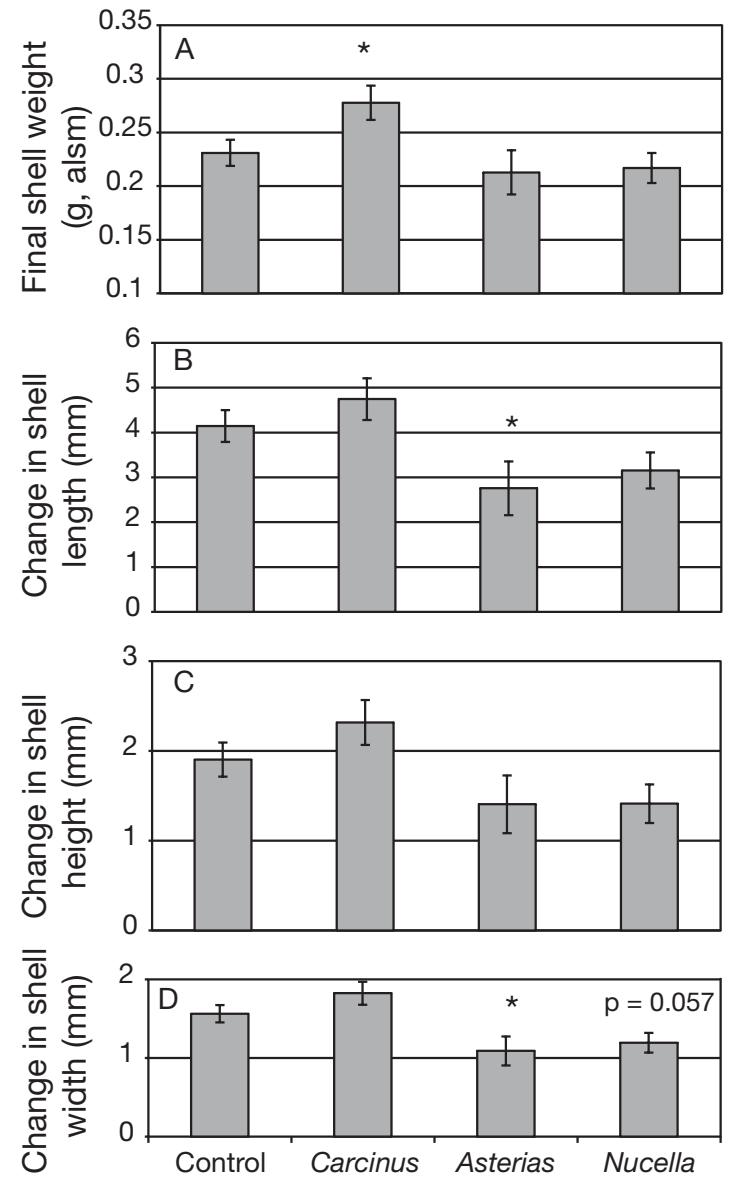
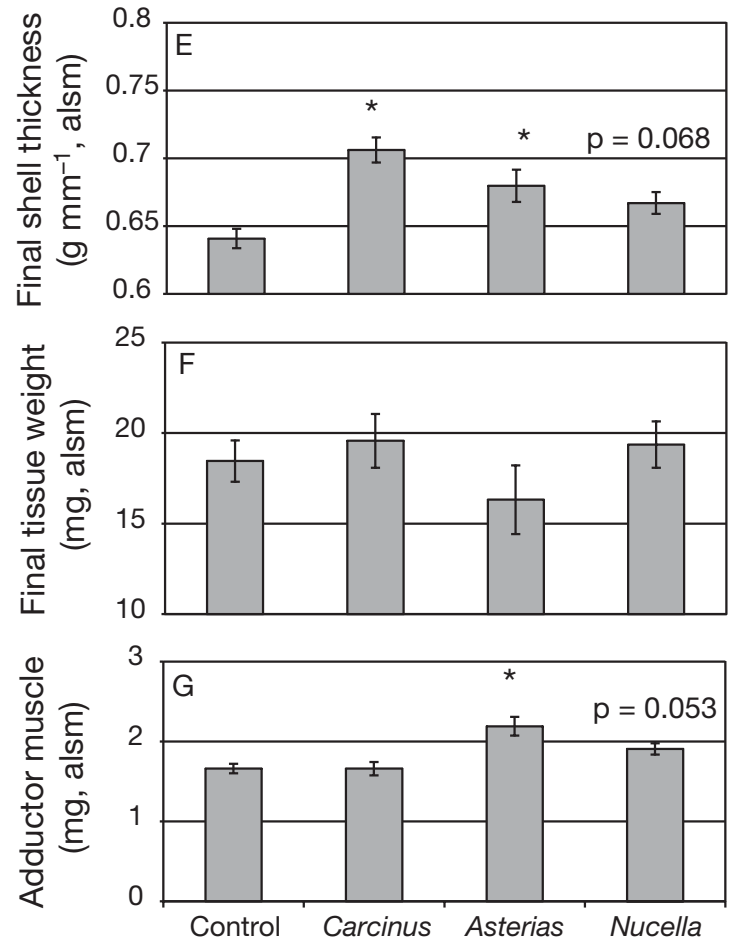

Fig. 1. Mytilus edulis. Final morphological measurements of mussels raised with various predator cues. Values for final shell dry weight (A) and final tissue weight (F) are adjusted least square means (alsm, \pm SE) from a nested ANCOVA with initial shell weight as covariate. Values for final shell thickness index (E) and final adductor muscle weight (G) are the least square means $( \pm \mathrm{SE})$ from an ANCOVA with final shell length and final tissue weight, respectively, as covariates. Values for change in shell length, width and height (1B-D) are least square means from an ANOVA. Error bars are \pm 1 SE *Significant difference from control treatment

the various predator treatments, was placed in each predation chamber with a crab. Each predation trial lasted $12 \mathrm{~h}$ with the first $1.5 \mathrm{~h}$ recorded on video. The water in each predation chamber was replaced between trials and another handling time observation begun using randomly selected mussels and the same crabs. This process was repeated, allowing all 10 crabs multiple opportunities to consume mussels from each predator cue treatment. After all trials were complete, 7 crabs had consumed 1 to 5 mussels from each of the 4 cue treatments ( 3 predator treatments plus the nopredator control) and 3 crabs had consumed 1 to 3 mussels from each of 3 cue treatments. A total of 74 observations were made of crabs consuming mussels. Previous trials indicated that similar sized C. maenas can consume $>10$ mussels in the size range used in this experiment in a $12 \mathrm{~h}$ period, suggesting that the crabs were not satiated during the above trials. I later exam- ined videos and estimated handling time from the moment the crab picked up the mussel until shell fragments were discarded and the crab continued searching. I then compared the handling times using an ANCOVA with each crab as a blocking factor and mussel length as a covariate, followed by a priori linear contrasts to compare the handling times of each predator treatment to controls. I also attempted to obtain handling times for Nucella lapillus; however, the whelk did not feed in the laboratory and was not used in subsequent predation trials.

Similar attempts to quantify handling times for Asterias vulgaris were visually obscured because the sea stars' oral (i.e. lower) surface was not visible to the camera above; however, recording predation trials from below yielded reliable estimates of handling times. In 2004, after raising mussels in a second cue experiment with $A$. vulgaris, Carcinus maenas or no- 
predator controls, and observing similar, predator specific induced defenses (A. Freeman unpubl. data), I ran a second predation experiment with $A$. vulgaris. For this I placed a rack of 9 glass bowls ( $15 \mathrm{~cm}$ diameter $\times$ $7 \mathrm{~cm}$ high) in a temperature controlled growth chamber $\left(15^{\circ} \mathrm{C}_{i} 1.4 \mathrm{~m}\right.$ high $\times 0.6 \mathrm{~m} \times 0.7 \mathrm{~m}$, internal dimensions), each containing $5 \mathrm{~cm}$ depth of unfiltered sea water and a single A. vulgaris (5.3 to $7.5 \mathrm{~cm}$, arm tip across oral disk). I obtained length $\times$ width $\times$ height measurements of randomly selected mussels raised in the cue experiment, placed a single mussel in each glass bowl and began recording time-lapse video from a camera placed $50 \mathrm{~cm}$ below the 9 glass bowls. These predation trials were run at least $8 \mathrm{~h}$ apart with no more than 2 trials in $24 \mathrm{~h}$. These trials were repeated until each of the 9 sea stars had consumed 1 to 5 mussels from each of the 3 cue treatments. A total of 73 predation events were observed. By viewing the oral surface of sea stars preying on mussels, I was able to estimate handling time from the moment the sea star began opening the mussel to when the mussel valves opened and the sea star changed position and began digesting the mussel. These handling times were analyzed using an analysis of variance with $A$. vulgaris identity as a blocking factor and mussel shell height as a covariate, followed by a priori linear contrasts to compare the handling times of each predator treatment to controls.

\section{RESULTS}

The MANOVA indicated that waterborne cues from the various predators significantly affected mussel morphology and growth (Table 1). A subsequent univariate ANOVA indicated that final shell weight was affected by cue treatment (Fig. 1a, Table 1). Mussels raised in the presence of cues from Carcinus maenas significantly increased their shell weight, while shell weight of Asterias vulgaris and Nucella lapillus-exposed mussels were not affected. All changes in shell length, width, and height showed similar patterns to each other, but the changes in shell length and shell width showed a significant treatment effect (Fig. 1b-d, Table 1). A. vulgaris-exposed mussels had significantly reduced changes in shell length and width relative to control mussels, whereas $N$. lapillus-exposed mussels had nearly significant reduced shell widths $(p=0.058)$. The type of predator cue also had a significant effect on the shell thickness index (Fig. 1e, Table 1). Linear contrasts indicated that mussels exposed to C. maenas, A. vulgaris or $N$. lapillus had higher shell thickness indexes than control mussels. Total tissue weights of mussels showed no treatment effect (Table 1); however, the amount of soft tissue allocated towards adductor muscle was significantly greater in A. vulgaris-exposed mussels (and N. lapillus to a lesser degree) than control mussels (Table 1, Fig. 1g).

Table 1. Mytilus edulis. Growth responses to cues from Carcinus maenas, Asterias vulgaris, Nucella lapillus and controls. Univariate and multivariate tests were conducted on the means of each replicate. Degrees of freedom for univariate ANOVA treatment and error terms were 3 and 15, respectively. Where regressions were used as scaling variables, the covariate appears in parentheses after the dependent variable. STI: shell thickness index

\begin{tabular}{|c|c|c|c|}
\hline $\begin{array}{l}\text { Full MANOVA } \\
\text { Source of variation }\end{array}$ & df & Wilks' $\lambda$ & F \\
\hline Treatment & $21,26.39$ & 0.0078 & $<0.0001$ \\
\hline $\begin{array}{l}\text { Univariate ANOVAs } \\
\text { Response variable }\end{array}$ & $F$ & $\mathrm{p}$ & A priori linear contrasts \\
\hline Final Shell Weight (Initial Shell Weight) & 3.656 & 0.0370 & $\begin{array}{l}\text { Carcinus }>\text { Control } \mathrm{p}=0.051 ; \text { Asterias vs. Control } \\
\mathrm{p}=0.367 ; \text { Nucella vs. Control } \mathrm{p}=0.454\end{array}$ \\
\hline Change in Shell Length & 4.462 & 0.0198 & $\begin{array}{l}\text { Carcinus vs. Control } \mathrm{p}=0.343 ; \text { Asterias }<\text { Control } \\
\mathrm{p}=0.030 ; \text { Nucella vs. Control } \mathrm{p}=0.109\end{array}$ \\
\hline Change in Shell Height & 3.129 & 0.0571 & \\
\hline Change in Shell Width & 6.425 & 0.0052 & $\begin{array}{l}\text { Carcinus vs. Control } \mathrm{p}=0.189 ; \text { Asterias }<\text { Control } \\
\mathrm{p}=0.018 ; \text { Nucella vs. Control } \mathrm{p}=0.058\end{array}$ \\
\hline Final STI (Initial STI) & 7.923 & 0.0021 & $\begin{array}{l}\text { Carcinus }>\text { Control } \mathrm{p}=0.0003 ; \text { Asterias }>\text { Control } \\
\mathrm{p}=0.009 ; \text { Nucella vs. Control } \mathrm{p}=0.068\end{array}$ \\
\hline $\begin{array}{l}\text { Final Tissue Weight, mg } \\
\text { (Initial Shell Weight) }\end{array}$ & 0.910 & 0.4597 & \\
\hline $\begin{array}{l}\text { Adductor Muscle Weight, mg } \\
\text { (Total Tissue Weight) }\end{array}$ & 6.158 & 0.0061 & $\begin{array}{l}\text { Carcinus vs. Control } \mathrm{p}=0.838 ; \text { Asterias }>\text { Control } \\
\mathrm{p}=0.002 ; \text { Nucella vs. Control } \mathrm{p}=0.053\end{array}$ \\
\hline
\end{tabular}


Predation experiments revealed asymmetrical benefits of specific inducible defenses. When exposed to lethal Carcinus maenas, the mussels' predator cue treatment had a significant effect on handling time (Tables $2 \& 3$ ). Compared to handling times of control mussels that were not exposed to predator cues, $C$. maenas took approximately $48 \%$ longer to consume mussels previously exposed to cues from C. maenas $(\mathrm{p}=0.041), 72 \%$ longer to consume mussels previously exposed to cues from Asterias vulgaris ( $p=0.007$ ), and approximately $67 \%$ longer to consume mussels previously exposed to cues from Nucella lapillus ( $p=0.052)$. Similarly, the mussels' cue treatment significantly affected handling times of $A$. vulgaris (Tables $4 \& 5$ ). However, only mussels previously exposed to $A$. vulgaris cues had increased handling times relative to control mussels (i.e. $36 \%, p=0.019$ ).

\section{DISCUSSION}

Mytilus edulis can distinguish among the 3 predators and express inducible defenses appropriate to each predator's foraging strategy. However, the resulting effectiveness of these defenses is asymmetrical; the mussels' response to Carcinus maenas does not deter Asterias vulgaris, yet C. maenas is deterred by all 3 predator responses. This is due to distinct mechanisms of shell thickening. In the presence of cues from $C$. maenas, mussels develop thicker shells by allocating more to shell weight (see also Leonard et al. 1999).

Table 2. Analysis of Carcinus maenas handling times consuming mussels raised with waterborne cues from $C$. maenas, Asterias vulgaris, or Nucella lapillus (ANCOVA). Final

Shell Length $\times$ Treatment was not significant $(p=0.12)$

\begin{tabular}{|lrrrr|}
\hline Source & df & \multicolumn{1}{c}{ MS } & \multicolumn{1}{c|}{$F$} & \multicolumn{1}{c|}{$\mathrm{p}$} \\
\hline Treatment & 3 & 115.871 & 3.1261 & 0.0323 \\
Crab ID & 9 & 278.758 & 7.5207 & $<0.0001$ \\
Final Shell Length & 1 & 156.228 & 4.2150 & 0.0444 \\
Error & 60 & 37.065 & & \\
\hline
\end{tabular}

Table 3. Carcinus maenas handling times, SE, and a priori linear contrasts (vs. Control) when consuming mussels raised under 4 cue treatments. Handling time is the least squares mean (LSM) with final shell length as a covariate

\begin{tabular}{|lcccc|}
\hline Mussel cue treatment & Control & Carcinus & Asterias & Nucella \\
\hline Handling time, min (LSM) & 7.9 & 11.7 & 13.5 & 13.2 \\
SE & 1.3 & 1.3 & 1.5 & 2.2 \\
Post-hoc linear contrasts & & $\mathrm{p}=0.041$ & $\mathrm{p}=0.007$ & $\mathrm{p}=0.052$ \\
(vs. Control) & & & & \\
\hline
\end{tabular}

Table 4. Analysis of Asterias vulgaris handling times consuming mussels raised with waterborne cues from Carcinus maenas, A. vulgaris or no predator (ANCOVA). Final Shell Height $\times$ Treatment was not significant $(p>0.20)$

\begin{tabular}{|lrrrr|}
\hline Source & df & \multicolumn{1}{c|}{ MS } & \multicolumn{1}{c|}{$F$} & $\mathrm{p}$ \\
\hline Treatment & 2 & 5406.3 & 5.4481 & 0.0066 \\
Asterias ID & 8 & 1378.6 & 1.3892 & 0.2190 \\
Final Shell Height & 1 & 11691.7 & 11.7822 & 0.0011 \\
Error & 62 & 992.32 & & \\
\hline
\end{tabular}

Table 5. Asterias vulgaris handling times, SE, and a priori linear contrasts (vs. Control) when consuming mussels raised under 3 cue treatments. Handling time is the least squares mean (LSM) with Final Shell Height as a covariate

\begin{tabular}{|lrcc|}
\hline Mussel cue treatment & Control & Carcinus & Asterias \\
\hline Handling time, min (LSM) & 59.5 & 49.8 & 81.2 \\
SE & 6.0 & 6.9 & 6.8 \\
Post-hoc linear contrasts & & $\mathrm{p}=0.290$ & $\mathrm{p}=0.019$ \\
(vs. Control) & & & \\
\hline
\end{tabular}

Accretion of shell $\mathrm{CaCO}_{3}$ is not energetically costly relative to respiration costs; however, it is normally presumed to proceed at, or near, a maximum rate in other mollusks (Palmer 1992, but see Trussell 2002). In mussels, it appears that shell accretion is not maximized in the absence of predators, given that it is increased in the presence of cues from C. maenas.

Unlike the response to Carcinus maenas, mussel shells thickened in response to cues from Asterias vulgaris (and to a lesser extent, Nucella lapillus) by decreasing linear shell growth but not altering shell accretion (i.e. adjusted final shell weights did not differ between predator cue treatments). Moreover, mussels developed relatively larger adductor muscles in response to waterborne cues from $A$. vulgaris (and to a lesser extent, $N$. lapillus) but not in response to C. maenas (Fig. 1G, Table 1). Although this increase in adductor muscle mass is accompanied by a decrease in linear shell growth, this is probably not an energetic trade-off, as the adjusted final shell weight remained unchanged in the presence of $A$. vulgaris (Fig. 1A, Table 1). This apparent trade-off may represent an adaptive response (providing less surface area for the sea star to grasp) or a mechanical necessity (a thicker shell is less likely to break when resisting the stronger adductor muscle) (Kautsky et al. 1990, Reimer \& Tedengren 1996).

In contrast to the significant and specific responses of mussels to Asterias vulgaris and Carcinus maenas, mussels did not show such strong responses to Nucella lapillus. In response to the whelk, mussels did not alter 
shell weight but showed reductions in linear growth (length, weight, or height), effectively thickening their shells and deterring $C$. maenas predation. In addition, mussels increased relative adductor muscle weight in response to $N$. lapillus, suggesting that these mussels would be protected from sea star predation. Given that $N$. lapillus largely drills through mussel shells to access soft tissue, the adaptive significance of mussels increasing adductor muscle size is perplexing. Occasionally, N. lapillus feeds on mussels through their gaping shell (Ebling et al. 1964), suggesting that shell closure is an adaptive response to the whelk. However, another whelk in the region (Buccinum spp.) often feeds on mussels by prying their valves open to access soft tissue, causing mussels to close tightly (Thompson 2002). If mussels express an induced defense to Buccinum spp., increasing their adductor muscle would likely deter the whelk. As such, mussels may have imperfect cue recognition (i.e. they may be unable to distinguish between $N$. lapillus and Buccinum spp.) and thus they may respond in an over-generalized way to cues from different whelks. Although no costs of induced defenses were observed in this study, similar cases of mistaken identity in mollusk predators can entail costs of induced defense with no defensive benefit (Langerhans \& DeWitt 2002).

Predator specific responses may also be influenced by size specific predation. For instance, gastropods responding to chemical cues from gape limited decapod predators can increase their growth rates to attain a size refuge from these predators (Crowl \& Covich 1990). While mussels can attain a size refuge from Carcinus maenas (Ebling et al. 1964) they generally do not have a size refuge from whelks and sea stars (Hunt \& Scheibling 1998, Saier 2001). Thus, there is likely an adaptive advantage for mussels in maintaining high growth rates and shell accretion in response to cues from $C$. maenas. In contrast, there is little or no adaptive advantage to rapid growth in responses to Nucella lapillus and Asterias vulgaris. Indeed, reduced linear shell growth may be an adaptive response to Asterias spp., as it provides a sea star with less surface area against which to pull mussel valves open (Reimer \& Tedengren 1996). Finally, mussels may be under pervasive selection to maximize feeding rates, growth rates, and reproductive output through high immediate growth. Any reduction in growth may result in 'opportunity costs' of reduced future growth and reproduction (Harvell 1990).

Although these induced defenses are specific to a predator's attack strategy, they may also influence predator behaviors, and indirectly affect handling times. For instance, sea stars adjust their position and the pulse duration of shell pulling based on the size and shape of a mussel's shell (Norberg \& Tedengren
1995). As a consequence, mussels with large, rigid shells but relatively weak adductor muscles (e.g. Carcinus maenas-exposed mussels) are consumed rapidly by a sea star, while mussels with small, rigid shells and strong adductor muscles may be consumed by a slower, 'siege strategy' (Norberg \& Tedengren 1995). Similarly, handling and consumption of mussels by C. maenas is influenced by shell thickness and shape, but may also be affected by the mussel's ability to resist perimeter assaults (prying, gape entry etc) (Moody \& Steneck 1993). The effectiveness of a perimeter assault is likely influenced by valve closure ability, which depends on adductor muscle strength.

In many situations, predator species may be segregated by habitats; sea stars rarely forage in the high intertidal (Lubchenco \& Menge 1978), whereas crabs predation is less intense in high flow sites (Leonard et al. 1999). This leads to spatially predictable patterns in the expression of inducible defenses (Leonard et al. 1999, Frandsen \& Dolmer 2002). Similarly, sea star and crab populations often fluctuate seasonally and annually, tracking mussel populations (e.g. Navarrete et al. 2000, Saier 2001, Witman et al. 2003), creating temporal variation in induced defenses that may influence their adaptive value. Because many inducible defenses develop slowly relative to community changes in predator assemblage, time lags in the expression of inducible defenses may represent fitness costs not normally considered in adaptive phenotypic plasticity (Padilla \& Adolph 1996, DeWitt et al. 1998, Van Buskirk 2002).

Temporal variation in predator abundance and time lags in the expression of induced defenses can be detrimental to mollusks expressing induced defenses to specific predators (DeWitt et al. 2000). This can be seen in the present study as mussels exposed to Carcinus maenas cues and subsequently preyed upon by Asterias vulgaris were not defended (and possibly may have been more vulnerable to the sea star). In contrast, mussels were effectively defended against $C$. maenas regardless of the previous predator cues (i.e. C. maenas, A. vulgaris, or Nucella lapillus). Due to this asymmetrical benefit of the induced defense, predation by $C$. maenas may reinforce the inducible defenses specific to $A$. vulgaris and $N$. lapillus, a pattern consistent with diffuse selection. Diffuse selection is often indicated when the adaptive value of traits influencing interactions with a predator species are altered through interactions with additional predator species (Strauss et al. 2005). Findings in the present study are of interest, as the adaptive value of induced defenses are frequently interpreted as only being influenced by a single target predator (but see Cipollini 2004). Moreover, although diffuse selection is often invoked to describe how responses to similar predators can be reinforced (Stinch- 
combe \& Rausher 2001, Van Buskirk 2001, Laforsch \& Tollrian 2004), the present study is the first to suggest that specific responses to predators are reinforced by predators with a different attack strategy.

Finally, because Mytilus edulis expresses inducible defenses appropriate to the predator's foraging strategy, both when predators are feeding (Reimer \& Harms-Ringdahl 2001) and when the predators are not feeding, the present study suggests that cues are emanating directly from the predators. Temporary reductions in mussel feeding behavior occur in response to crushed conspecifics, but not to predator cues per se (A. Freeman \& J. Meszaros unpubl. data). Accordingly, if cue predators are feeding on crushed conspecifics, behaviorally mediated reduced growth could be confounded with predator specific induced defenses. Mussels in the present study were able to actually increase shell weight without slowing linear growth in response to $C$. maenas, perhaps because the predators were not fed (for comparisons see Smith \& Jennings 2000, Reimer \& Harms-Rindgahl 2001). The ability of mussels to respond to non-feeding predators allows them to express these induced defenses, even though predators may be in the area but feeding on alternative prey (e.g. barnacles). Because mussels will also respond to crushed conspecifics (Leonard et al. 1999), responding to these additional cues may additively increase the defensive morphology expressed (Trussell \& Nicklin 2002).

In conclusion, although several studies have independently examined the effects of individual predators on induced defenses of Mytilus edulis, a comparison of the impacts of different predators reveals that mussels can distinguish between non-feeding predators and respond with induced defenses appropriate to the predator's attack strategy. The induced response to several predators effectively increased handling time by the crab, Carcinus maenas, but not the sea star Asterias vulgaris. Thus, in addition to an apparent absence of costs of the inducible defense (i.e. no reduced tissue growth), costs associated with time lags in the expression of induced defenses are also minimized, as mussels responding to all 3 predators are defended from the invasive crab, C. maenas. The high specificity of the mussel's response to predators and the apparent general effectiveness of the various defenses may facilitate the diffuse selection of these inducible defenses; however, it will also be important to examine the simultaneous effect of these predator cues.

Acknowledgements. For support during this work, I thank N. Carlson, M. Chalfoun, UNH Marine Program, UNH Zoology Department, UNH COLSA Graduate School, and the Great Bay NERR GRF. Earlier versions of this paper were improved by comments from I. Altman, M. Bertness, A. Blakeslee, J. Byers, J. Dijkstra, B. Griffen, M. Lesser,
J. Meyer, M. Scott, G. Trussell, and 2 anonymous reviewers. This is part of a dissertation submitted to the Graduate School at the University of New Hampshire as a requirement for completion of a doctoral degree.

\section{LITERATURE CITED}

Appleton RD, Palmer AR (1988) Water-borne stimuli released by predatory crabs and damaged prey induce more predator-resistant shells in a marine gastropod. Proc Natl Acad Sci 85:4387-4391

Black AR (1993) Predator-induced phenotypic plasticity in Daphnia pulex: life-history and morphological responses to Notonecta and Chaoborus. Limnol Oceanogr 38: 986-996

Cheung SG, Lam S, Gao QF, Mak KK, Shin PKS (2004) Induced anti-predator responses of the green mussel, Perna viridis (L.), on exposure to the predatory gastropod, Thais clavigera Kuster, and the swimming crab, Thalamita danae Stimpson. Mar Biol 144:675-684

Cipollini D (2004) Stretching the limits of plasticity: Can a plant defend against both competitors and herbivores? Ecology 85:28-37

Clark CW, Harvell CD (1992) Inducible defenses and the allocation of resources-a minimal model. Am Nat 139: 521-539

Crowl TA, Covich AP (1990) Predator-induced life-history shifts in a fresh-water snail. Science 247:949-951

DeWitt TJ, Sih A, Wilson David S (1998) Costs and limits of phenotypic plasticity. Trends Ecol Evol 13:77-81

DeWitt TJ, Robinson BW, Wilson DS (2000) Functional diversity among predators of a freshwater snail imposes an adaptive trade-off for shell morphology. Evol Ecol Res 2: 129-148

Ebling FJ, Kitching JA, Muntz L, Taylor CM (1964) The Ecology of Lough Ine: XIII. Experimental observations of the destruction of Mytilus edulis and Nucella lapillus by crabs. J Anim Ecol 33:73-82

Frandsen RP, Dolmer P (2002) Effects of substrate type on growth and mortality of blue mussels (Mytilus edulis) exposed to the predator Carcinus maenas. Mar Biol 141: 253-262

Harvell CD (1984) Predator-induced defense in a marine bryozoan. Science 224:1357-1359

Harvell CD (1990) The ecology and evolution of inducible defenses. Q Rev Biol 65:323-340

Hunt HL, Scheibling RE (1998) Effects of whelk (Nucella lapillus (L.)) predation on mussel (Mytilus trossulus (Gould), M. edulis (L.)) assemblages in tidepools and on emergent rock on a wave-exposed rocky shore in Nova Scotia, Canada. J Exp Mar Biol Ecol 226:87-113

Iyengar EV, Harvell CD (2002) Specificity of cues inducing defensive spines in the bryozoan Membranipora membranacea. Mar Ecol Prog Ser 225:20 5-218

Kautsky N, Johannesson K, Tedengren M (1990) Genotypic and phenotypic differences between Baltic and North Sea populations of Mytilus edulis evaluated through reciprocal transplantations I. Growth and morphology. Mar Ecol Prog Ser 59:203-210

Laforsch C, Tollrian R (2004) Inducible defenses in multipredator environments: cyclomorphogenesis in Daphnia cucullata. Ecology 85:2302-2311

Langerhans RB, DeWitt TJ (2002) Plasticity constrained: overgeneralized induction cues cause maladaptive phenotypes. Evol Ecol Res 4:857-870

Leonard GH, Bertness MD, Yund PO (1999) Crab predation, 
waterborne cues, and inducible defenses in the blue mussel, Mytilus edulis. Ecology 80:1-14

Lively CM (1986) Predator-induced shell dimorphism in the acorn barnacle Chthamalus anispoma. Evolution 40: $232-242$

Lubchenco J, Menge BA (1978) Community development and persistence in a low rocky intertidal zone. Ecol Monogr 48: 67-94

Matsuda H, Abrams PA, Hori H (1993) The effect of adaptive antipredator behavior on exploitative competition and mutualism between predators. Oikos 68:549-559

Moody KE, Steneck RS (1993) Mechanisms of predation among large decapod crustaceans of the Gulf of Maine coast: Functional vs. phylogenetic patterns. J Exp Mar Biol Ecol 168:111-124

Moran NA (1992) The evolutionary maintenance of alternative phenotypes. Am Nat 139:971-989

Navarrete SA, Menge BA, Daley BA (2000) Species interactions in intertidal food webs: prey or predation regulation of intermediate predators? Ecology 81:2264-2277

Norberg J, Tedengren M (1995) Attack behaviour and predatory success of Asterias rubens L. related to differences in size and morphology of the prey mussel Mytilus edulis L. J Exp Mar Biol Ecol 186:207-220

Padilla DK, Adolph SC (1996) Plastic inducible morphologies are not always adaptive: the importance of time delays in a stochastic environment. Evol Ecol 10:105-117

Palmer AR (1982) Growth in marine gastropods: a nondestructive technique for independently measuring shell and body weight. Malacologia 23:63-73

Palmer AR (1992) Calcification in marine molluscs: How costly is it? Proc Natl Acad Sci 89:1379-1382

Reimer O, Harms-Ringdahl S (2001) Predator-inducible changes in blue mussels from the predator-free Baltic Sea. Mar Biol 139:959-965

Reimer O, Tedengren M (1996) Phenotypical improvement of morphological defenses in the mussel Mytilus edulis induced by exposure to the predator Asterias rubens. Oikos 75:383-390

Relyea RA (2001) Morphological and behavioral plasticity of larval anurans in response to different predators. Ecology 82:523-540

Saier B (2001) Direct and indirect effects of seastars Asterias rubens on mussel beds (Mytilus edulis) in the Wadden Sea. J Sea Res 46:29-42

Smith DC, Van Buskirk J (1995) Phenotypic design, plasticity,

Editorial responsibility: Roger Hughes (Contributing Editor), Bangor, UK and ecological performance in 2 tadpole species. Am Nat 145:211-233

Smith LD, Jennings JA (2000) Induced defensive responses by the bivalve Mytilus edulis to predators with different attack modes. Mar Biol 136:461-469

Stinchcombe JR, Rausher MD (2001) Diffuse selection on resistance to deer herbivory in the ivyleaf morning glory, Ipomoea hederacea. Am Nat 158:376-388

Strauss SY, Sahli H, Conner JK (2005) Toward a more traitcentered approach to diffuse (co)evolution. New Phytol 165:81-90

Thompson J (2002) The influence of hunger and olfactory cues on the feeding behavior of the waved whelk, Buccinum undatum, on the blue mussel, Mytilus edulis. Veliger 45:55-57

Trussell GC (1996) Phenotypic plasticity in an intertidal snail: the role of a common crab predator. Evolution 50:448-454

Trussell GC (2002) Evidence of countergradient variation in the growth of an intertidal snail in response to water velocity. Mar Ecol Prog Ser 243:123-131

Trussell GC, Nicklin MO (2002) Cue sensitivity, inducible defense, and trade-offs in a marine snail. Ecology 83: $1635-1647$

Trussell GC, Smith LD (2000) Induced defenses in response to an invading crab predator: an explanation of historical and geographic phenotypic change. Proc Natl Acad Sci 97 : 2123-2127

Turner AM, Fetterolf SA, Bernot RJ (1999) Predator identity and consumer behavior: differential effects of fish and crayfish on the habitat use of a freshwater snail. Oecologia 118:242-247

Van Buskirk J (2001) Specific induced responses to different predator species in anuran larvae. J Evol Biol 14:482-489

Van Buskirk J (2002) Phenotypic lability and the evolution of predator-induced plasticity in tadpoles. Evolution 56: $361-370$

Wares JP (2001) Biogeography of Asterias: North Atlantic climate change and speciation. Biol Bull 201:95-103

Whitlow WL, Rice NA, Sweeney C (2003) Native species vulnerability to introduced predators: testing an inducible defense and a refuge from predation. Biol Invasions 5:23-31

Witman JD, Genovese SJ, Bruno JF, McLaughlin JW, Pavlin BI (2003) Massive prey recruitment and the control of rocky subtidal communities on large spatial scales. Ecol Monogr 73:441-462

Submitted: February 7, 2006; Accepted: July 3, 2006

Proofs received from author(s): March 8, 2007 